\title{
Editorial
}

Digestion

\section{Is Low-Dose Aspirin Really Harmful to the Small Bowel?}

\author{
István Rácz
}

Department of Gastroenterology, Petz Aladár County and Teaching Hospital, Győr, Hungary

There is no doubt that even low-dose aspirin as well as conventional non-steroidal anti-inflammatory drugs (NSAIDs) cause gastroduodenal ulcers and erosions in $6-30 \%$ of patients receiving such drugs $[1,2]$. It is also well known that both conventional NSAIDs and COX-2 inhibitors result in small bowel damage in humans either during a short- or long-term treatment period [3]. The capsule endoscopy method is an emerging technique for assessing small bowel damage. Using capsule endoscopy, small bowel changes were found in up to $70 \%$ of the volunteers taking NSAIDs or COX-2 inhibitors with over a third having mucosal breaks (erosive-ulcerative damage) [4-6]. The precise pathogenesis is uncertain, but it seems likely that local topical effects involving NSAID-membrane phospholipid interaction and uncoupling of mitochondrial oxidative phosphorylation which compromises intestinal integrity might play a role [3].

Low-dose aspirin (75-325 mg daily) has become the most commonly prescribed medication for prevention of cardiovascular events. However, until recently, the risk of aspirin-induced gastroduodenal damage was almost exclusively studied and no studies have been published on the causal relationship between low-dose aspirin and small bowel injury.

The pilot study using capsule endoscopy reported by Endo et al. [7] in this issue of Digestion examined the incidence of small bowel injury in healthy volunteers treated with low-dose enteric-coated aspirin for 14 days. Healthy subjects were randomly assigned to receive low- dose aspirin or no drugs for 14 days by a crossover method including a washout period for at least 4 weeks. After 2 weeks of treatment, significantly higher percentages of subjects in the aspirin group compared to the control group ( 80 vs. $20 \%$ ) had small bowel pathology, however, there was no significant difference in the incidence of small bowel mucosal breaks. The main conclusion of this crossover but small size study is that the short-term administration of low-dose aspirin is associated only with 'mild' mucosal inflammation of the small bowel. This interesting and pioneer investigation draws the attention to several issues which will probably be studied more extensively in the future:

First, in this study the low-dose aspirin-induced small bowel mucosal effects were investigated by capsule endoscopy without knowing exactly what the consequences of full-dose aspirin medication would be in the small bowel mucosa. All previous small bowel capsule endoscopy studies were dedicated to drug-induced morphological alterations focused on NSAIDs and/or COX-2 inhibitors and never targeted a subgroup of patients on a fulldose aspirin therapy, at least for a short period.

Second, the pathophysiology of the suspected aspirininduced small bowel injury is basically unknown, however, it should be at least partly dissimilar to the aspirin damage in the gastroduodenal area where the acidic intraluminal $\mathrm{pH}$ plays a major role in aspirin-provoked mucosal toxicity.

\section{KARGER}

Fax +4161306 1234 E-Mail karger@karger.ch www.karger.com (c) 2009 S. Karger AG, Basel

0012-2823/09/0791-0042\$26.00/0

Accessible online at:

www.karger.com/dig
Prof. István Rácz, MD

Department of Gastroenterology, Petz Aladár County and Teaching Hospital

Vasvári P. u. 2-4, HU-9024 Győr (Hungary)

Tel. +3696418 244, ext. 1150, Fax +3696418486

E-Mail raczi@petz.gyor.hu 
Third, this study also indicates how difficult it is to describe the small bowel lesions in terms of their extent and severity. The authors used the six-category intestinal mucosal damage classification first described by Maiden et al. [8] as well as the capsule endoscopy index for small bowel mucosal inflammatory changes published recently by Gralnek et al. [9]. The Maiden classification also includes petechiae, red spots and reddened folds, while the scoring index includes only three parameters: villous edema, ulcer and stenosis. Nevertheless, considering the fact that only 3 out of the 10 subjects in the aspirin group presented mucosal breaks and according to the capsule endoscopy score none of the low-dose aspirin-treated subjects developed moderate or severe changes, one might conclude that the results do not prove a heightened effect of low-dose aspirin treatment in the small bowel.
Fourth, low-dose aspirin treatment is usually indicated in the long term, however, the results of a short-term study do not automatically reflect the potential long-term mucosal effects of aspirin treatment. One of the most important clinical questions is whether in certain cases lowdose aspirin therapy induces occult bleeding resulting in chronic iron deficiency anemia is still a challenging problem. The authors also state that it is unknown whether long-term aspirin users need medical therapy.

In conclusion, the demonstration of low-dose aspirininduced mild enteropathy suggests the need to define the extent of this potential problem. Increasing clinical awareness and further appropriate investigations are needed to establish the proper diagnosis.

\section{References}

1 Yeomans ND, Lanas AI, Talley NJ, Thomson AB, Daneshjoo R, Eriksson B, AppelmanEszczuk S, Langstrom G, Naesdal J, Serrano P, Singh M, Skelly MM, Hawkey CJ: Prevalence and incidence of gastroduodenal ulcers during treatment with vascular protective doses of aspirin. Aliment Pharmacol Ther 2005;22:795-801.

-2 Yeomans ND, Lanas A, Labenz J, Veldhuyzen van Zanten S, van Rensburg C, Rácz I, Tchernev K, Karamanolis D, Roda E, Hawkey C, Nauclér E, Svedberg LE: Efficacy of esomeprazole (20 mg once daily) for reducing the risk of gastroduodenal ulcers associated with continuous use of low-dose aspirin. Am J Gastroenterol 2008;103:2465-2473.

$\checkmark 3$ Fortun JJ, Hawkey CJ: Nonsteroidal anti-inflammatory drugs and the small intestine. Curr Opin Gastroenterol 2005, 21:169-175.
4 Graham DY, Opekun AR, Willingham FF, Qureshi WA: Visible small-intestinal mucosal injury in chronic NSAID users. Clin Gastroenterol Hepatol 2005;3:55-59.

5 Maiden L, Thjodleifsson B, Theodors A, Gonzalez J, Bjarnason I: A quantitative analysis of NSAID-induced small bowel pathology by capsule endoscopy. Gastroenterology 2005;128:1172-1178.

6 Goldstein JL, Eisen GM, Lewis B, Gralnek IM, Zlotnick S, Fort JG: Video capsule endoscopy to prospectively assess small bowel injury with celecoxib, naproxen plus omeprazole, and placebo. Clin Gastroenterol Hepatol 2005;3:133-141.
Endo H, Hosono K, Inamori M, Kato S, Nozaki Y, Yoneda K, Akiyama T, Fujita K, Takahashi $\mathrm{H}$, Yoneda M, Abe Y, Kirikoshi H, Kobayashi N, Kubota K, Saito S, Matsuhashi N, Nakajima A: Incidence of small bowel injury induced by low-dose aspirin: a crossover study using capsule endoscopy in healthy volunteers. Digestion 2009;79:44-51.

$\checkmark 8$ Maiden L, Thjodleifsson B, Seigal A, Bjarnason II, Scott D, Birgisson S, Bjarnason I: Long-term effects of non-steroidal antiinflammatory drugs and cyclooxygenase- 2 selective agents on the small bowel: a crosssectional capsule enteroscopy study. Clin Gastroenterol Hepatol 2007;5:1040-1045.

9 Gralnek IM, De Franchis R, Seidman E, Leighton JA, Legnani P, Lewis BS: Development of a capsule endoscopy scoring index for small bowel mucosal inflammatory change. Aliment Pharmacol Ther 2008;27: 146-154. 